Stanistaw Bylina (Warsaw)

\title{
Image of the Heretic in Late Medieval Poland
}

In a Bohemian metrical anti-Hussite pamphlet of 1421 we are introduced to a negative character under the name of Tábor, ${ }^{1}$ who could be easily associated with the name of recently established militant group of Hussite reformers, hated by the Catholic camp. In a discussion with Václav, an orthodox worshiper of the patron of the Bohemian Crown, Tábor shows his true colours of a model heretic - the Hussite. ${ }^{2}$

Possessed by false dogmas of the 'new faith', persevering in his errors, he is neither able nor willing to accept arguments of his opponents. Every now and then he refers to the Holy Bible which he interprets as he chooses, in a perverse way, rejecting the authority of the Roman Church and its tradition. But at the same time he blindly believes in the infallibility of the self-proclaimed priests and preachers of his sect. $\mathrm{He}$ is a canter, liar and hypocrite, faking his inspiring piety. Being filled thoroughly by hatred, wrath and lust for violence, he wishes to slaughter priests, burn down churches and plunder Church possessions in the name of the usurped 'law of God'. Denying the value of Catholic rites and liturgy, he replaces them by his faith in a beneficial value of the Hussite 'chalice' - communion in both kinds. He provocatively despises the rules applying to all true Christians: despite it being Friday, he scandalises Václav by taking a roast out of his bag. The monstrosity

1 'Vaclav, Havel a Tábor', in Versované skladby doby husitské, ed. by F. Svejkovsky, Prague, 1963, pp. 116-50.

2 Cf. among others, S. Bylina, 'Polemika z herezją w wierszowanych utworach antyhusyckich', in Slawistyczne studia literackie poświęcone VII Międzynarodowemu Kongresowi Slawistów, Wrocław, 1973, pp. 71-82. 
of Tábor's opinions and actions is accompanied by the ugliness of his behaviour and appearance. The man is shouting and shaking a bat at his quiet interlocutor, he is violent, impulsive, bleak and pale out of anger, and he averts his gaze from others.

Here is the heretic par excellence, a creature brought to life by a member of the Catholic camp, meant for a mass audience as an instrument of didactics and anti-Hussite propaganda. In spite of the indisputable literary creativeness of the anonymous author we are given a figure which could seem coarse, schematic and drawn in a uniformly bleak colour. But in his pedigree he has ancestors from past centuries. For the model heretic - Hussite was born not only out of an atmosphere of violent ideological clashes, but also of traditions of antiheretical polemics of the thirteenth and fourteenth centuries. Individual elements of the discussed image, the psychical traits of the heretic - stubbornness, vehemence, wrath, perfidiousness, hypocrisy - were the components of the knowledge, persevered in the clerical communities, about the foes of the faith and the Church, passed down through generations in polemical treatises, literary works, chronicles and sermons, both written and preached. ${ }^{3}$

This knowledge was also shaped by the development of theological writings in pre-Hussite Bohemia. It was gaining timeliness during occasionally recurring actions of the inquisition in that country, aimed against the Waldenses who constituted a quite large group of immigrant Germans. ${ }^{4}$ Finally, the presence of that knowledge and its dissemination were determined by the place of the Kingdom of Bohemia within the German Reich in the time of the Luxembourg dynasty and its opening up for civilisation influences of the Empire (in which the struggle against heresies was a part of Church and political life) and of Western Europe.

The lands of the Polish Kingdom that are the subject of our reflections had a different reality and different traditions. The fact that in fifteenth-century Poland there was no literary counterpart of the heretic Tábor resulted mainly from the lack of phenomenon analogous or similar to the Czech mass socio-religious movement, called Hussitism, which was accompanied by ideological debates reflected in writings. Furthermore, the

3 On this, see E. Potkowski, 'Stereotyp heretyka-innowiercy w piśmiennictwie kaznodziejskim', in Kultura elitarna a kultura masowa w Polsce późnego średniowiecza, ed. by B. Geremek, Wrocław, 1978, pp. 121-35 (here the basic literature on the subject). 4 Quellen zur böhmischen Inquisition im 14. Jahrhundert, ed. by A. Patschovsky, Weimar, 1979, pp. $71 \mathrm{ff}$. 
image of the heretic - created in the Polish lands in the fifteenth century as the result of preventive measures taken by the Church and state and of the real, although limited reflections of Hussitism - was almost devoid of its earlier, local origins. The lack of tradition of antiheretical polemics could be easily explained by an almost total absence of mass movements of religious heterodoxy in the Polish lands, both in the fourteenth as in the previous centuries. In the fourteenth century the papacy was establishing, by special papal bulls, inquisitors for the analysed territory, ${ }^{5}$ but this seems to be a preventive and universal action, aimed at all countries of Western Christianity, rather than a response to a sense of threat to the orthodoxy of the Church in Poland and its faithful. Anyway, the office of inquisition did not leave in the Polish Kingdom the most obvious trace of its operations in the form of records of interrogations of people suspected of heresy or blasphemy. Meaningful is also the absence of issues concerning fights against heresy in the texts of resolutions of diocesan synods. Similarly, Polish historiography before Długosz remains silent on the subject, writing down in annals ${ }^{6}$ and occasionally in chronicles ephemeral appearances of flagellants in the thirteenth and fourteenth century, even though regarded as a movement detrimental to the Church, but not always as a heretic one. The absence of mass heretic movements in the lands of the Polish Kingdom was probably perceptible for foreigners, since it was noticed by a true authority on heresiology, the German Inquisitor Peter Zwicker. In his treatise from the end of the fourteenth century he meticulously listed the blissful lands with no Waldenses he fought against, including 'the kingdom of Cracow' (that is, the Polish Kingdom), where 'there are almost no Waldenses' and where 'all people are practically well protected' against the sect. ${ }^{8}$

Sparse source material and enigmatic meaning of scant texts telling us rather about presumed traces of heresy in the lands of the Polish Kingdom before the fifteenth century have induced modern historians to broaden

5 K. Dobrowolski, 'Pierwsze sekty religijne w Polsce', Reformacja w Polsce, 3, 1924, pp. 24 ff.; J. Mikulka, Polské země a herese v době pred reformaci, Prague, 1969, pp. $20 \mathrm{f} ., 28 \mathrm{f}$.

6 Chronicle records of 1261 concerning flagellants are compiled by W. Korta, Średniowieczna annalistyka ślaska, Wrocław, 1966, p. 211.

7 'Kronika Wielkopolska', in Monumenta Poloniae Historica, vol. 2, Lviv, 1872, p. 587.

8 Quoted after R. Cegna, 'Idea wolności w ruchach heretyckich późnego średniowiecza: waldyzm europejski', Kwartalnik Historyczny, 86, 1979, 4, p. 963. 
the scope of their research and to include the neighbouring territories that in the fourteenth century did not belong to the Polish Crown: Silesia, Western Pomerania, and sometimes the lands belonging to the state of the Teutonic Order. They have been following in the footsteps of Kazimierz Dobrowolski, the author of the still fundamental text on heresies in the Polish lands, ${ }^{9}$ the scientific value of which stems mainly from the analysis of sources from Silesia and Pomerania. Indeed, more recent research, and especially editions of sources undertaken by foreign historians, demonstrated a mass development of Waldensian movement in Pomerania in the second half of the fourteenth century and a presence of little-known so far splinter groups of religious heterodoxy in Silesia. ${ }^{10}$ Whereas the attempts at shedding a new light on the lands of Little Poland and Great Poland, resulting in various - often valuable - findings (for instance, how heresies crept in from neighbouring countries), as well as suggestions and assumptions put forth ${ }^{11}$, have not changed the overall image of the lands of the Polish Kingdom as a country with no heretic movements. Even more fruitless had been previous attempts to demonstrate the existence of heretical thought and ideology in the Polish medieval society at the expense of a too arbitrary interpretation of the sources. ${ }^{12}$

9 Dobrowolski, op. cit., pp. 161-202.

10 See esp. Quellen zur Ketzergeschichte Brandenburgs und Pommerns, ed. by D. Kurze, Berlin and New York, 1975. In the Polish literature on the subject: W. Swoboda, 'Waldensi na Pomorzu i w Nowej Marchii w świetle protokołów szczecińskiej inkwizycji z lat 1392-1394', Materiaty Zachodniopomorskie, 19, 1973 (1979), pp. 493-509. Cf. also A. Patschovsky, 'Waldenserverfolgung in Schweidnitz 1315', Deutsches Archiv für Erforschung des Mittelalters, 36, 1980, pp. 137-76 (for instance, the problem of accusations against the Waldenses charged with the so-called Luciferianism).

11 Mikulka, op. cit., pp. 9-46; W. Swoboda, 'Początki herezji na ziemiach polskich', in Europa - Stowiańszczyzna - Polska, Poznań, 1970, pp. 385-96; Historia Kościoła w Polsce, ed. by B. Kumor and Z. Obertyński, Poznań and Warsaw, 1974, pp. 258 ff.; J. Wyrozumski, 'Beginki i begardzi w Polsce', Zeszyty Naukowe UJ, 261 (Prace Historyczne, 35), 1971, pp. 7-22; 'Z dziejów waldensów w Polsce średniowiecznej', Zeszyty Naukowe UJ, 469 (Prace Historyczne, 56), 1977, pp. 39-51; D. Lapis, B. Lapis, 'Beginki w Polsce w XIII-XV wieku', Kwartalnik Historyczny 79, 1972, 3, pp. 521-44. There has been also published the interesting text of a $14^{\text {th }}$-century antiheretical treatise, probably functioning mainly in Silesia: O. P. Kielar, 'Traktat przeciw beghardom Henryka Hevrer', Studia Theologica Varsaviensis, 8, 1970, 2, pp. 231-52. The perspectives of research into the history of the Waldenses in the Polish lands are signalised by: Cegna, op. cit., p. 962. 12 Cf. for instance, E. Maleczyńska, Ruch husycki w Czechach i w Polsce, Warsaw, 1959, Chapter Five: 'U kolebki ideologii husyckiej'. 
In the light of what has been said above, the answer to the question about the image of the heretic in Poland before the fifteenth century is more an attempt to ascertain the possibility that there were functioning rudiments of knowledge about heresy rather than to discover actual antiheretical actions, bringing into being a stereotype of enemy of the faith and the Church. In the fourteenth century a certain part of this knowledge was available mainly to a small intellectual and Church elite: the people wielding power in the Church and theologians educated abroad. We should take into consideration an influence of Patristic texts; the works of the Fathers of the Church, containing a rich knowledge of heretics and sects of early Christianity, belonged to the reading lists of learned communities of the Church. Higher diocesan authorities were more familiar with the problem of contemporary heresies, even if only through papal bulls warning against 'foes of the Cross'. Church dignitaries in Poland knew also decrees of ecumenical councils condemning some heterodox communities. A certain terminology close to polemics against heretics was known to various groups of educated clergy, and among them to those who wrote historical texts. Although in records about the flagellant movement in the thirteenth century (1260-61) annalists were fascinated mainly by the external aspect of flagellantism (the motif of 'naked penitents' was recurring), there were also some stereotypical expressions used, known from antiheretical texts (the motif of the 'destruction of the Christian faith' as the alleged purpose of religious sects). There could also be found an eruditely display of names of old Christian sects, borrowed from Saint Isidore of Sevilla, that were said to have initiated subsequent heresies. ${ }^{13}$

The knowledge about heretics as the foes of the faith and the Church against which the faithful had to be protected also reached the parish clergy. According to the questionnaire in force, parish priests should be questioned about heretics during ecclesiastical visitation, with specific names of the sects currently fought against by the Roman Catholic Church. ${ }^{14}$ The parish clergy, on the other hand, was obliged to preach

13 'Rocznik kapituły krakowskiej' (Annals of the Cracow Chapter), in Monumenta Poloniae Historica, Series Nova, vol. 5, ed. by Z. Kozłowska-Budkowa, Warsaw, 1978, pp. 28-30.

14 Questions about the presence of heretics and specifically of Beghards and Beguines are included in the questionnaire published by S. Librowski, 'Wizytacje diecezji włocławskiej', Archiwa, Biblioteki i Muzea Kościelne, 8, 1964, pp. 170-71. 
to the faithful about the sin of heresy, at least vaguely. It should be especially done in the Lent, when registers of sin categories were read to the faithful, indicating the sinners who could not receive Easter's Holy Communion without a special absolution from the bishop. ${ }^{15}$ The terms included in such a register, especially those that could have not been generally understood, should have been explained. In the awareness of the audience an image of the heretic was created as a great sinner, excluded both from the broadest Christian community and the narrow one, of the parish, for which a yearly participation in the Sacrament of Eucharist was an important sign of unity. This was strengthened by the knowledge imparted to the faithful during parish teachings that a Church funeral was denied to the excommunicated. ${ }^{16}$ Not without importance for the shaping of images of heresy and heretics was their position within the above mentioned prohibitory letters. In the early fourteenth century (1320) heretics were situated next to witches and soothsayers, forgers and false witnesses, and blasphemers. ${ }^{17}$ All these terms were associated in the antiheretical tradition with the errors against the faith and the lèse-majesty divine. A part of them (witches, soothsayers and blasphemers) was to be found in the text of manuals for inquisitors operating in the fourteenth century in Western Europe. ${ }^{18}$

The role of the sermon as an instrument to propagate the ideas of heresy that shaped the image of the heretic in fourteenth-century Poland requires further research. In many countries of Western Christianity, including neighbouring Bohemia, it was simply fundamental. Sunday sermons on the Gospel exhibited the motif of heresy in relation to certain Evangelic verses, especially those which related to false prophets, weeds among the wheat, or the bad tree bearing evil fruit. Various categories of sinners were described, among whom heretics had a reserved place.

15 Cf. J. Wolny, 'Z dziejów katechezy', in Dzieje teologii katolickiej w Polsce, ed. by M. Rechowicz, vol. 1: Średniowiecze, Lublin, 1974, p. 194.

16 A. Labudda, Liturgia pogrzebu w Polsce (do wydania Rytuatu Piotrkowskiego 1631), Warsaw, 1983, p. $239 \mathrm{ff}$.

17 Najstarsze statuty synodalne krakowskie biskupa Nankera z 2 października 1320 r., ed. by J. Fijałek, Cracow, 1915, pp. 59-60.

18 Cf. for instance: Bernard Gui, Manuel de l'Inquisiteur, ed. by G. Mollat, vol. 2, Paris, 1964, pp. 21-26; N. Eymerich, F. Pena, Le manuel des inquisiteurs, ed. by L. Sala-Molins, Paris, 1973, pp. 63-67. Cf. also E. Potkowski, 'Haeresis et secta maleficorum. Powstanie stereotypu', in Cultus et cognitio. Studia z dziejów średniowiecznej kultury, Warsaw, 1975, pp. 477 f. 
Edward Potkowski demonstrated that it was sermons that were the most successful in the creation of the medieval stereotype of the heretic as a wolf in sheep's clothing, 'the son of Satan', false pious, a haughty and perfidious man. ${ }^{19}$ We should remember, however, the limited reach of parish preaching in Poland before the fifteenth century; it was to reach its prime only after the renovation of Cracow University. ${ }^{20}$ It seems, moreover, that also in those town churches (parish or monastic) in which Sunday preaching was already an established occurrence, the problem of heresy did not belong to frequent themes, for it had no direct reference to the local reality, both of the Church and the society.

In the countries where the activities of mass religious social movements condemned by the Church belonged to their reality, one of the factors that strongly influenced the collective awareness and imagination of the faithful was great actions of hunting down heretics, famous trials before Inquisition courts and above all executions of people handed over to civil authorities that made indelible impression. Where the atmosphere of searching the guilty, denouncements, examinations and repressions was not directly experienced, where people did not come across those peculiar spectacles of solemn abjurations and public punishments of incorrigible culprits, the image of the heretic had to be distant and vague. A significant majority of the inhabitants of the fourteenth-century Polish Kingdom did not encounter, even indirectly, the area of antiheretical operations, of suspicion and anxiety. Of course, there were also those who used to go abroad, even if only to Pomerania, Silesia or Bohemia, and who could have brought exciting news of people going against the Church and their harsh punishments. But even in such information there was always an element of strangeness. And in Poland an accusation of heresy was not a weapon used in political conflict. It was not used in disputes between the Church and the state, it was not charged against people in the public eye. It was not until the next century that the label of believer or henchman of heresy became one of the components of political culture, but not overused (let us remind the case of alleged Hussite Spytko of Melsztyn, embroiled in the rivalry for influence inside the state). ${ }^{21}$

19 Potkowski, Stereotyp heretyka..., op. cit., passim.

20 Cf. mainly, J. Wolny, 'Kaznodziejstwo', in Dzieje teologii..., op. cit., pp. 275-308.

21 Cf. for instance, A. Sochacka, 'Konfederacja Spytka z Melsztyna z 1439 r. Rozgrywka polityczna czy ruch ideologiczny?', Rocznik Lubelski, 16, 1973, pp. 41-65. 
In Poland the contours of the image of the heretic began only to surface before the fights against Hussites. In this poor and still vague image there were recognisable stamps of inexpiable sin of heresy, enmity towards the faith and the Church, exclusion from the faith and community, probably also of some vices and offences forming the stereotype which was known for a long time in the countries of Western Christianity. Soon after the Hussite wars began in Bohemia, the problem of heresy appeared in Poland with a new, much greater force. Under the threat felt by the Church, supported by the monarchy, the question of heresy became present on various planes of Church life and in the Church and state influence on the people.

A new vision of heresy and heresies followed relatively soon, closely related to the Hussite context, adapted to the current situation, needs of its authors and propagators. An important contribution to the emergence of the vision was made by a community of Bohemian Catholic emigrants, especially those who had been associated with Prague University and came to Cracow. ${ }^{22}$ With this creative community was connected an import of theological antiheretical thought, subsequently developed in the Polish lands, and also of texts that were helpful in fighting heresies. The prehistory of the Hussite movement and its beginning were the subject of observations and experiments of Cracow theologians of Polish origins who had studied at Charles University. There were also among Polish theologians and Church dignitaries those who had participated in the Council of Constance, witnesses to the long and famous trial of Jan Hus. The intellectuals of Cracow of the first decades of the fifteenth century were to hand over their knowledge and achievements to the Catholic Church in Poland fighting Hussitism. Here were written treatises containing anti-Hussite contents, works of canonists devoted to problems of heresy, and collections of sermons meant for the clergy and the laity.

The image of the heretic Hussite was developed in Poland mainly within the sphere of defensive, preventive and propaganda actions of guards of the orthodoxy of the Polish Church and state rather than being a result of encounters of Christian orthodoxy with actual Hussite influences. It was an instrument of the Church influence upon the faithful,

22 Cf. for instance, J. Garbacik, S. Strzelecka, 'Uniwersytet Jagielloński wobec problemów husyckich w XV wieku', in Acta Universitatis Carolinae. Historia Universitatis Carolinae Pragensis, Prague, 1964, fasc. 1-2, pp. 7-52. 
but also a tool of antagonisms between the clergy and the laity, bitter in the fifteenth century. It should be noted here that in Poland actual sympathies for the Hussite religious doctrine and for the Hussite Church and its social programme, especially in its radical version, were extremely rare, and concerned very few people. More frequent, however, till the end of the fifteenth century, were - in some Polish lands, in particular among the nobility and the townspeople - attitudes modelled on Hussites or close to them as regards religious practices and liturgy or the place of the laity and the clergy within the Church. Yet, in general, these phenomena were perfunctory and ephemeral; the foci of Hussite followers appeared and disappeared, and only in some territories, for instance in Great Poland, they had a tendency to regenerate. The described religious movement, called conventionally the Polish Hussitism, had generally no broader social reach, ${ }^{23}$ although occasionally it included also people from the lower social strata. Sometimes, like at Zbąszyń, the vitality of the Hussite centre was determined by an influential figure of local lord whose stance impinged upon his closest milieu and the townspeople, the lord who shielded activities of Hussite priests. ${ }^{24}$

Before that, however, with regard to the events in Bohemia, the Church authorities in Poland were expecting stronger Hussite threats. The importance of legal Church and state acts issued in the 1420s for a stereotype of heretic formed later lies more in the fact of their propagation within the society than in their implementation. The Remedia contra hereticos included in the statutes of Archbishop Mikołaj Trąba (1420) were to be published in churches and addressed to lay authorities at various levels. ${ }^{25}$ They contained basic information about the heretics as the believers of Jan Hus's doctrine condemned by the Church. They presented the heretic as an individual dangerous to Christians that should be denounced to the proper Church authorities. Those who arrived from Bohemia were a priori suspected of sympathies towards

23 It extent was exaggerated in many works published in the 1950s and 1960s, including the only so far comprehensive synthesis by E. Maleczyńska (op. cit.). A concise and balanced characteristic of the 'Polish Hussitisme' is presented by S. Trawkowski, in Zarys historii Polski, ed. by J. Tazbir, Warsaw, 1979, pp. 130-33.

24 Apart from older works, on the Zbąszyń centre of Hussite followers, cf. Mikulka, op. cit., pp. 63-72, 113-19.

25 'Remedia contra hereticos', in Statuty synodalne wielun'sko-kaliskie z r. 1420, ed. by J. Fijałek, A. Vetulani, Cracow, 1915-51, pp. 95-96. 
the heresy; later on, the identification of the heretic with a Bohemian became an important element of the image of the follower of error. The edict of Wieluń, issued by Władysław II Jagiełło in 1424, stating precisely - from the perspective of the lay authorities - preventive means and punishments for the guilty of heresy, ${ }^{26}$ introduced an unknown so far in Poland identification of errors against the Catholic faith with the crime of lèse-majesté. According to this assumption, known in the states which had to fight against heresies in previous centuries, the heretic - an enemy of the faith and the Church, was at the same time the enemy of the monarch and the state. In Poland, in later years the consequence of such an approach was a new conceptual cluster in the form of double accusation of heresy and 'high treason', that is sympathies towards the foes of the Kingdom and contacts with them. ${ }^{27}$ The Edict of Wielun, whose punishments were modelled on the thirteenth-century constitutions of Frederic $\mathrm{II}^{28}$ and the legal tradition of that century, ${ }^{29}$ reduced heretics to the category of people sentenced to infamy, threatening them with banishment, confiscation of property and deprivation of noble status, if they were nobles. Such a stance towards the guilty of the 'crime of heresy' was continued in later acts announced publicly, in which they were regarded as 'unworthy of noble status'. ${ }^{30}$

It is right to point out here the declarative and propaganda character of the Edict of Wieluń, since in practice, as far as it is known, its most severe resolutions were not enforced, and outside of Little Poland its effect seemed to have been illusory. We hear of no trials that could have been evident consequences of reprisals. In later years, pro-Hussite sympathies of individuals from the circle of powerful ones (in Polish: możni) of Great Poland, like Abraham Zbąski, for some time under the Church's interdict, did not destroy or even did not hamper their public

26 Volumina Legum, vol. 1, ed. by J. Ohryzko, Petersburg, 1859, p. 38.

27 Acta Capitulorum nec non iudiciorum ecclesiasticorum selecta, ed. by B. Ulanowski (hereafter, A. Cap.), vol. 2 (Acta iud. eccl. Poznaniensis), Cracow, 1902, p. 487 (1431). 28 Monumenta Germaniae Historica, Legum Sectio IV, Constitutiones et Acta, vol. 2, Hannover, 1896, pp. 107-09, 281-85. Cf. also K. Koranyi, 'Konstytucje cesarza Fryderyka II przeciw heretykom i ich recepcja w Polsce', in Ksiega pamiątkowa ku czci Wtadystawa Abrahama, vol. 1, Lviv, 1930, pp. 317-40.

29 H. Maisonneuve, 'Le droit romain et la doctrine inquisitoriale', in Études d'histoire du droit canonique, vol. 2, Paris, 1962, pp. 931-42.

30 Codex epistolaris Vitoldi magnis ducis Lithuaniae, ed. by A. Prochaska (Monumenta Medii Aevi Historica, vol. 6), Cracow, 1880, no. 1155. 
career and activity. ${ }^{31}$ Also Polish towns did not demonstrate ardour for victimising heretics and they did not introduce into their municipal laws (in Polish: wilkierze) the prosecution for heresy.

Theologians and especially experts on the canon law developed also the theory, already not a new one, that heresy - lese-majesty divine - was a much more grave crime than the lese-majesty human, an offence against the power of the king (Stanisław of Skarbimierz). ${ }^{32}$ There was brought up too, in the context of the Polish-Teutonic conflict, the need to punish those guilty of heresy with the assistance of the secular arm, invoking the example of the fair capital punishments for Jan Hus and Jerome of Prague. ${ }^{33}$ This Church-state-legal point of view brought into circulation (although of a limited scope) the concept of heretic as criminal. In official rulings pertaining to some cases of heresy the Church correspondence spoke of 'criminal statements' 34 or 'crimes' (in the case of the Polish Wycliffite, Master Jędrzej Gałka). ${ }^{35}$ Closer to canonists, however, was a traditional conceptual apparatus, derived from the arsenal of antiheretical Church writings. Paweł Włodkowic, who in anti-Teutonic polemics used the tactic of accusations of heresy against the 'Prussian sect', tried to demonstrate that heretics were more evil than Jews and pagans (Saracens) because knowing the principles of the Gospel of Jesus Christ, they still destroy the Christian faith. ${ }^{36}$ In accordance with the content and rhetoric of earlier antiheretical texts, he accused the champions of errors of hypocrisy and actions that destroyed the Church. ${ }^{37} \mathrm{He}$ called heresy a kind of superstition, ${ }^{38}$ thus referring to the motif of its close relation to witchcraft and magic.

In the sphere of theological university knowledge of the first part of the fifteenth century, antiheretical polemics turned into the direction of fight

31 A. Gąsiorowski, 'Husyty Abrahama Zbąskiego działalność publiczna', Śląski Kwartalnik Historyczny Sobótka, 36, 1981, pp. 139-45.

32 Stanistaw of Skarbimierz, Sermones sapientiales, ed. by B. Chmielowska, vol. 3, Warsaw, 1979, p. 311.

33 Pisma wybrane Pawta Wtodkowica, ed. by L. Ehrlich, vol. 1, Warsaw, 1968, p. 211 (a treatise Ad Aperiendam).

34 Codex epislolaris saeculi decimi quinti, vol. 2, Cracow, 1882, no. 176 (a sentence on the Master of the University of Cracow, Henryk of Brzeg).

35 Ibid., vol. 1, Part 2, no. 63 (Elgot's letter to Zbigniew Oleśnicki, 1449).

36 Pisma wybrane Pawta Wtodkowica, op. cit., p. 199.

37 Ibid.

38 Ibid., p. 196. 
against Utraquism..$^{39}$ The problem of Hussite 'chalice', communion in both kinds administered to the laity, neither of dogmatic nor ecclesiological character, eclipsed other aspects of the Catholic-Hussite argument. Yet, it was understood that the postulate of Utraquism was the most evident and highly valued by the Hussites symbol of their religious programme. In Poland it was regarded as the symbol of its open split with the tradition and practice of the Roman Catholic Church. A theoretic polemic with Utraquism paved the way for later propagation of this notion as an identification mark of the heresy and occasionally the only theme of accusations of its profession and practice. In the explanation of the theological knowledge of heretics, directed to a wider audience, reducing the contemporary heresy to Utraquism was insufficient. In preaching, addressed also to the clergy, the image of the heretic was becoming richer and more colourful than in specialist treatises. Although such terms as: followers of Wycliff's and Hus teaching, Hussites and Utraquists, were still vital, yet they functioned within a broader field of knowledge related to heresy and its concepts, themes and rhetoric phrases. In sermons delivered by Stanisław of Skarbimierz the heretic operated in the dark ${ }^{40}$ because darkness was associated with the sphere of evil, sin and error, set against the light of Christian orthodoxy. A well-known motif of antiheretical polemics combined the spiritual darkness of the sinning and erring man with the darkness of his mind - heresy was often seen as the manifestation of a lack of true religious knowledge. It was also combined with the darkness of nature: adherents of sects were active during the night, the time of criminals and evil spirits, gathering in their secret meetings and rituals. ${ }^{41}$ But the darkness around the heretic was permanent and impenetrable for he, himself being blind and not seeing the truth, was teaching other blind men. He was wading through a dark labyrinth of errors and could not find an exit. ${ }^{42}$ The heretic was also a blasphemer, for by his propagation of errors, and even worse, by initiating new ones,

39 M. Rechowicz, 'Po założeniu Wydziału Teologicznego w Krakowie (wiek XV)', in Dzieje teologii..., op. cit., p. 137; W. Schenk, 'Z dziejów liturgiki', ibid., pp. 257-58.

40 Stanisław of Skarbimierz, Sermones sapientiales, op. cit., pp. 297-312.

41 Cf. on this subject, S. Bylina, 'Heretycy w społeczeństwie. Świadectwo czeskich źródeł inkwizycyjnych z XIV wieku', Kwartalnik Historyczny, 89, 1982, 1, p. 113.

42 Stanisław of Skarbimierz, Sermones sapientiales, op. cit., pp. 301, 308. 
he insulted God. ${ }^{43}$ Preaching introduced into the image of the heretic a relatively rich set of comparisons, numbering in a large part among the traditionally used in earlier polemic writings of the Church. Wolf in sheep's clothing, wolf in the sheepfold, the tempting serpent or small fox (known from the Song of Songs) belonged to often applied idioms. The preacher compared heretics to hungry dogs roaming about the town and trying to snatch for something. ${ }^{44}$ Thus, the Church was drawing on the well-known in the Middle Ages symbols of sins and wrongs, on the models from the books of the Old and New Testaments.

Polish homilies of the fifteenth century associated, by various lexical means, heretics with the world of evil and sin. They assimilated them to false prophets known from the Gospel, ${ }^{45}$ messengers of the devil who perfidiously transformed into angels of the light in order to attract adherents of their teachings. ${ }^{46}$ Occasionally, in this layer of considerations in which of certain significance was an eschatological perspective, the heretic was being put in hell. He was denied the grace of remittance after death, for the purifying fire of purgatory expiated only some minor sins that remained to be purged away. That denial he shared with the schismatic, idolater, sodomite, murderer, blasphemer and other categories of the vilest sinners. ${ }^{47}$ But the heretic brought into being in Poland crept to hell in a modest and largely unnoticed way. In sermons, literary texts and visual arts he did not belong to the exposed dwellers of hell, tormented by fire and compelled to drink tar and sulphur as a cautionary example and admonishment of the faithful. His quiet, albeit obvious casting down into hell ${ }^{48}$ was a small part of the religious culture of the country which until recently had not known heresy, which at any rate was not numbered among the most vital and burning problems of late medieval Christianisation.

43 Stanislaus de Scarbimiria, Sermones super 'Gloria in Excelsis', ed. by R. M. Zawadzki, Warsaw, 1978, p. 76.

44 Stanisław of Skarbimierz, Sermones sapientiales, op. cit., p. 304.

45 [Mikołaj of Błonie], Sermones venerabilis magistri Nicolai de Btony... de tempore et de sanctis, Strassburg, 1498, 11. 289r ff.

46 A. Brückner, Literatura religijna w Polsce średniowiecznej, vol. 1: Kazania i pieśni, Warsaw, 1902, p. 84.

47 Stanislaus de Scarbimiria, Sermones super 'Gloria in Excelsis', op. cit., p. 133.

48 This is in Mikołaj of Błonie, op. cit., 1l. 289r-91r. 
In spite of concerns of the Church in Poland, fuelled within the circle of Zbigniew Oleśnicki by the urge to demonstrate the orthodoxy of the state, heresy was not seen in the likeness of an apocalyptic plague. The vision of Christianity seized by heretics was held only by those who inclined towards prophetic trends, awaiting divine retribution sent to punish a sinful world. Overwhelmed by the burden of prevailing vices and progressing decline of the Christian world the theologian Jacobus of Paradiso warned the Church against imminent great plagues. $\mathrm{He}$ included among them pestilences, violence and atrocities of heretics, invasions of pagans violating Christian nations. ${ }^{49}$ A prophetic vision of heretics as servants of Antichrist wreaking havoc on the eve of the end of times, in Poland did not play an important part either in the formation of elitist or popular model of man erring in his faith. The situation in the Universal Church, prompting concern and involvement of Polish theologians in work on reform, was not connected, contrary to the West, to the development of catastrophic and millenarian conceptions. Heretic remained a weapon of mundane ideology and propaganda addressed to both inside and outside of the country, and not a personage predestined to a certain role in eschatological drama of the Church and mankind.

At the beginning of the second half of the fifteenth century in Poland an image of the heretic was being created for the contemporaries and descendants, intended, according to its author, to function within a certain ideological programme of the Church and state. The image was produced by Długosz, a historian who did not belong to the circle of academic intellectuals and whose theological knowledge of heresiology was quite superficial. The chronicler, relating the history of Hussitism, skilfully used texts by other authors (especially the History of Bohemia by Enea Silvio Piccolomini), ${ }^{50}$ and he also knew the opinions on Hussitism of the community of Cracow University, of the Cracow Chapter and of Zbigniew Oleśnicki himself. He also had a selection of commonplace, stereotypical terms and concepts about heretics and heresy. Such an arsenal of knowledge he filled in with his creativity, drawing on his own antipathy to the Bohemian heresy, its authors, ideologues, and rank

49 'De Septem statibus Ecclesiae in Apocalypsi mystice descriptis', in Jakub z Paradyża, Wybór tekstów dotyczących reformy Kościoła, ed. by S.A. Porębski, Warsaw, 1978, p. 32. 50 Cf. on this subject, S. Solicki, Źródła Jana Długosza do problematyki czeskiej, Wrocław, 1973, pp. 112-24; U. Borkowska, Treści ideowe w dziełach Jana Długosza. Kościół i świat poza Kościołem, Lublin, 1983, p. 148. 
and file followers. In Długosz, a key idea of the interpretation of Hussitism was to contrast the heretical pestilence in Bohemia with the most immaculate orthodoxy of Polish Christianity, successfully defending the purity of the faith of the Church in Poland, the Polish monarchy protecting its people against dangers from outside influences, and also exerting itself to re-Catholicise neighbouring Bohemia. ${ }^{51}$ Thus, the historian presented such an image of the Bohemian heresy and heretics as to make them most repugnant to the Polish audience and emphasise their detrimental, destructive role. Urszula Borkowska in her analysis of Długosz's vision of Hussitism paid attention to the frequency of terms relating to diseases, plagues and deadly poisons. ${ }^{52}$ The chronicler, using a comparison, known from antiheretical writings, of heresy destroying the Church to a disease eating away at the human body, in his image of the heretic attributed him with symptoms of an infected person and thus dangerous for the healthy. He employed the terminology known already in the Polish Church (used, for instance, by Zbigniew Oleśnicki) and in regulations of the secular authorities. ${ }^{53}$ Portraits of well-known leaders of the Bohemian Hussite movement ${ }^{54}$ were painted with the means known from the tradition of antiheretical polemics, with the addition of new individual traits, based on the assessment of the part played by those figures in relatively recent or even current events. Jan Žižka, 'the blind leader of a blind people', became the model of the cruel man, destroyer of churches and murderer of priests, cunning and sly commander who used his talents to destroy Christianity. Jan Rokycana, a theologian and Hussite preacher, 'the head of the Bohemian heresy', was described as a villainous and deceptive master of his fellow believers deceived by him, hideous in his every deed, repugnant even in his sickness - a deserved Divine retribution sent on him for the infinity of his sins. He was quite similar to the figure of the leper, regarded in the Middle Ages with fear mixed with disgust and contempt. Bohemian heretics were heartless and ruthless, with hardened minds and hearts. Those who came to Cracow to conduct a dispute with Catholic theologians (1431) were not moved even by the beautiful words of Polish King Władysław II Jagiełło who

51 Cf. remarks in Borkowska, op. cit., p. 169.

52 Ibid., pp. 152-53.

53 Codex epistolaris Vitoldi, no. 1155; Codex epistolaris saeculis decimi quinti, I, 2, no. 63 .

54 Borkowska, op. cit., pp. 156-59. 
deplored the ruin of the once glorious kingdom of Bohemia. ${ }^{55}$ The portrait of the Hussite heretic in the text by Długosz, created to the benefit of the Polish Church and the Catholic monarchy, had features of coherent and consistent composition. It revealed a profile of the evil and dangerous enemy. At the same time its author was aware that small concessions made to objectivise it would not destroy the impression made by the whole picture. Thus, he was able to provide the Hussite, apart from heretical obstinacy, envy and other vices, with such characteristics as an exemplary life, knowledge and finally dignity in the face of death. In the image of Polish adherents to Hussisim, however, this coherency of composition was upset, and the chronicler was no longer a portraitist engaging his talent, passion and knowledge into painted images, but became an author of small sketches. This was probably for two reasons. Firstly, there were in Poland no figures that could be used as models of heretics; secondly, Długosz did not exert himself to find them in the country whose orthodoxy he wanted to demonstrate. It was already pointed out that he omitted the (notorious in the community of Cracow Church and University of the late 1440s) case of heresy of Master Jędrzej Gałka, ${ }^{56}$ and pro-Hussite sympathies and Utraquist practices of Abraham of Zbaszyń he treated fairly casually, surprised that such a sensible man could have become embroiled in heretical errors. ${ }^{57}$ And last but not least, Długosz clearly saw disproportions between the ideology, significance and social reach of the Bohemian Hussite movement and its reflections in the Polish lands.

Both the ideological stereotype of heretic functioning in treatise writings and preaching, and the mythical monster brought to life by Długosz on the basis of alien models and the ideology accepted by him, made - in spite of many shared and universal elements - closed and separate images. Neither are they especially useful - apart from models propagated in mass preaching - for attempts to recognise images more widespread in popular consciousness and functioning in the society. In any case, the possibilities in this regard are rather limited. Certainly, the way through the sources written by Church courts investigating cases of Hussitism ${ }^{58}$ is not perfect, but it turns out to be the only one. These

55 Ibid., p. 151.

56 Cf. S. Kolbuszewski, Herezja kanonika Jędrzeja Gatki, Wrocław, 1964.

57 Borkowska, op. cit., p. 167.

58 These sources were used to study the ideological premises of Polish Hussitism, its territorial range etc., cf. Mikulka, op. cit., Chapter 2: 'Polské husitstvi'. 
sources, in accordance to their origins, mirror mainly the reality of the Church, attitudes and opinions of consistorial circles, they commonly use set phrases and include an abridged and edited record of the testimonies of the witnesses and the accused. In spite of all this, however, they record a certain picture of knowledge and images held by a broader and more representative group of the laity: noblemen, townsmen, minor Church officers, representatives of town and rural crafts, and also the parish clergy who often did not differ mentally from the laity.

In the image of the heretic reconstructed on the basis of the discussed sources we could distinguish the layer of basic designations and notions belonging to the anti-Hussite didactic programme addressed to a broader public. In the formulas of court sentences and acts of defection from heresy we find vulgarised contents from writings of elitist character. Court practice consistently identified the term of heretic with a Hussite and of heresy with Hussitism (and initially also with Wycliffism), ${ }^{59}$ preserving such a perception until the end of the fifteenth century. It is worth noting that this identification functioned in different layers of fifteenth-century culture; it is meaningful that glossers of Latin texts completed the terms of 'hereticus' and 'heretici' by the words 'husz' (Hussite) and 'huszovye' (Hussites). ${ }^{60}$ For lay people testifying in Church courts those terms were interchangeable or synonymous and it was obvious that they were correctly understood. But in colloquial speech greater role was played by the words 'heretic' and its synonym in Polish: 'kacerz. ${ }^{61}$ These words, which in anti-Hussite propaganda were synonyms of evil, in colloquial speech used by the community became terms of insult used in arguments and disputes, especially between clergy and laymen. A drunken parishioner called his parochial vicar a 'heretic' and 'liar', ${ }^{62}$ village inhabitants brought to a quarrel called one another 'heretics'. Insulting were also the words coined from the names of people symbolising the Hussite heresy: one of the parish inhabitants reviled his parish priest calling him a 'dog and

59 Cf. for instance, A. Cap., vol. 2 (Acta iud. eccl. Poznaniensis), p. 870 (1423).

60 E. Balcerzowa, Glosy polskie w tacinskich kazaniach średniowiecznych, Part 2, Wrocław, 1983, pp. 87, 95, 103.

61 Cf. the entries: 'hereticus', 'heretico' in Stownik taciny średniowiecznej w Polsce, vol. 4, Wrocław, 1977, col. 706. Cf. also the entries: 'kacerz', 'kacerstwo' in Stownik staropolski, vol. 3, Wrocław, 1960, p. 216; Balcerzowa, op. cit., Part 1, Wrocław, 1981, pp. 56, 88 .

62 A. Cap., vol. 3 (Acta iud. eccl. Wladislaviensis), Cracow, 1908, p. 226 (1428). 
rokycaner' ${ }^{\prime} 3$ (from the name of the dignitary of the Bohemian Utraquist Church, the already mentioned Jan Rokycana). Already in the past the Polish verb kacerzować was used in ordinary colloquial speech to mean 'accuse of heresy' but also to 'call names' and 'revile'. ${ }^{64}$ Thus the word 'heretic' became an invective, an accusation of heresy - a weapon used in various conflicts and antagonisms. It seems that a certain role in the dissemination of the insult of 'heretic' was played by parish clergy who used it against their antagonists, especially those who openly expressed their anticlerical attitudes. The label of heretic was applied also to those from the laity who showed too much criticism of the opinions expressed by priests and of their sermons, and also those who had ambitions to interpret the texts of the Holy Bible differently from the interpretations in churches. ${ }^{65}$ Suspicions of heresy could also have resulted from scandalous excesses insulting - in the eyes of the clergy - the Church liturgy. Some townsmen from the small town called Stawiszyn in the land of Calisia, who during their revelry parodied a mass and baptised young animals, were accused of acting 'according to the custom of Jan Hus' sect' ${ }^{66}$ It is certain, however, that the lay people, also those who were sympathetic towards certain elements of the Hussite programme of a poor Church and abolition of estate privileges of the clergy, associated heresy with evil, and in the heretic they saw the personification of many, frequently quite randomly selected vices.

The practice of Church courts and their phraseology disseminated the stereotype of the heretic Bohemian. Let us remind that in Poland already in the early years of the anti-Hussite defensive anyone who arrived from Bohemia was regarded with suspicion, and especially from Prague - a nest of errors (yet in later years it turned out that the Hussite past and stay in this heretic country did not necessarily hamper one's career) ${ }^{67}$ In any case, those suspected of Hussite practices (receiving the Eucharist under the forms of both bread and wine) were obliged to swear that they would never make a journey to Bohemia. ${ }^{68}$ The term

63 A. Cap., vol. 2 (Acta iud. eccl. Poznaniensis), pp. 575-76 (1456).

64 Stownik staropolski, op. cit., p. 216.

65 Cf. for instance, A. Cap., vol. 3 (Acta iud. eccl. Wladislaviensis), p. 269 (1499).

66 A. Cap., vol. 2 (Acta iud. eccl. Calisiensis), p. 904 (1460).

67 Cf. A. Gąsiorowski, 'Kariera Piotra Polaka z Lichwina (1428-1441)', Studia

i Materiaty do Dziejów Wielkopolski i Pomorza, 14, 1980, 1 (27) pp. 32-45.

68 Cf. for instance, A. Cap., vol. 2 (Acta iud. eccl. Poznaniensis), p. 592 (1468). 
'Hussite heresy' became interchangeable with the 'sect of Czechs heretics', 'Bohemian sect', 'Bohemian articles' (of the faith) etc. ${ }^{69}$

A new element was included into the model of the heretic or someone suspected of heresy: contacts with Czechs or any relation with Bohemia, Czech nation and its representatives. It is worth to remind here Długosz's efforts to prove that Poles encountering Czechs during their anti-Teutonic expedition did not succumb to this heretic pestilence, but on the contrary - they hated it even more.

The faithful were taught that suspected of heresy were those who visited the 'suspected places' (loca suspecta) - ill-famed places in the eyes of an orthodox Catholic. In the territory of Great Poland as such were regarded both the distant centre of heresy in Prague and nearer, better known towns: Zbąszyń and Kębłów. ${ }^{70}$ It was quite common to refer to that fama publica of certain places, their inhabitants and individuals. ${ }^{71}$ It was a phenomena known from the history of heresy and its prosecutions. ${ }^{72}$ In spite of the fixed and functioning opinion (a heretic was someone who came from or inhabited a place known for a great number of heretics) the interrogated were induced to express it by their desire to dissociate themselves from any suspicions. Thus, the shadow of heresy was located in other, even neighbouring, towns.

It could be assumed that in the awareness of the general public the concept of heretic was narrowed down to the man practicing Utraquism or approving of this rite of communion under both kinds. Starting from the 1430s to the end of the century Utraquism was the main and often the only theme of accusation of heresy. It was also the only substantial

69 Cf. for example, ibid. (Acta iud. eccl. Gneznensis), p. 103 (1437); ibid. (Acta iud. eccl. Poznaniensis), p. 535 (1443), 563 (1449).

70 Ibid. (Acta iud. ccci. Poznaniensis), p. 554 (1445): 'Insuper iuraverunt amodo nee in Bohemia nec in Kyeblowo vel Dzbanschyn aut ad alia loca suspecta visitare, excepta aliqua causa racionabili, et hue cum licencia ordinarii loci'.

71 Cf. for example, ibid., vol. 3 (Acta iud. eccl. Plocensis), pp. 9-10 (1453); ibid. (Acta iud. eccl. Wladislaviensis), p. 243 (1480). We could refer here to the opinion of a cleric about a heretical neighbourhood - ibid. (Acta iud. eccl. Wladislaviensis), p. 243 (1480): 'Incipiendo a Corzecznyk usque ad Krziwoszandza ista tota plaga posset iuste comburi propter heresim'.

72 Cf. on the subcject, S. Bylina, 'Sind Häretiker Fremde in der Gesellschaft?', Acta Poloniae Historica, 50, 1984, pp. 24 ff. 
element of the formula of abjuration. ${ }^{73}$ It is known, however, that the inclusion in the register of heretical practices of the communion under both kinds was not generally accepted. For a part of the Polish society, although probably a small one, the idea and practice of Utraquism was authentically attractive. It would be difficult to answer the question whether it was induced by the desire to remove the difference between the clergy and the laity in approaching communion or whether receiving the Eucharist sub utraque speciae gave richer and deeper spiritual experience. For some, Utraquism could have been only an attractive novelty, a passing religious fashion. Regardless of the actual role of these motivations, the attitudes of adherents or only sympathisers of the discussed practice of communion ground the uniformity of image of the heretic Utraquist popularised within the society.

Much lesser part in the dissemination of the image of the heretic Hussite was played by the iconophobia ${ }^{74}$ transferred into the Polish lands from the reality of Hussite Bohemia. There were attempts to implant it in Poland on the basis of episodic events that were, however, of quite dubious ideological premises. Those, who were said to have turned upside down sacred images at a church in a certain town of Great Poland, most probably were rowdies who had quarrelled with a local altarist, broke into his household and destroyed his furniture. ${ }^{75}$ It is also known that there were attempts to fix the label of Hussite iconoclasm to the plunderers of Jasna Góra Sanctuary, who damaged the miraculous picture of the Virgin Mary. It seems that this version of the event in which Długosz saw a mere robbery ${ }^{76}$ preserved in the later tradition, could have been an important factor of the iconophobia motif in the fifteenth-century image of the heretic.

In the wake of early antiheretical statutes Church courts associated the figure of heretic or someone suspected of heresy with books they owned, with contents against the true faith. In the beginning, it was texts by Hus

73 Cf. for instance, A. Cap., vol. 2 (Acta iud. eccl. Poznaniensis), pp. 522-23, 525 (1441), 533 (1442).

74 Cf. on the subject, A. Gieysztor, 'Lassitude du gothique? Reflets de l'iconoclasme hussite en Pologne au XV siècle', in Ars auro prior. Studia Joanni Biatostocki sexagenario dicata, Warsaw, 1981, pp. 223-26.

75 A. Cap., vol. 2 (Acta iud. eccl. Poznaniensis), p. 556 (1446).

76 Joannis Dlugosii Historia Polonica, vol. 4, Cracow, 1887, p. 399. 
and other 'heresiarchs', ${ }^{77}$ later the list of incriminated books was much longer. Suspicions were cast on religious texts written in vernaculars (in vulgari), not only in the Bohemian language but also in Polish, or mixed texts: Latin-Polish. ${ }^{78}$ The way from asserting the possession of dubious books to accusations of sympathies towards heresy and Utraquist practices was quite short. In the laymen's opinion the possession, and especially dissemination of codices of unknown, mysterious content (sometimes single phrases or words were remembered) ${ }^{79}$ was one of the symptoms of heresy. This conviction was strengthened when someone little-known and lacking in significance (like a certain townsman from the neighbourhood of Łowicz) was rumoured to be a 'great heretic' and to possess many heretical books. ${ }^{80}$ The spread of lay literacy and intensification of circulation of handwritten books in Poland, apart from its other consequences, reinforced the repressive actions of the Church, and at the same time it shaped a new model of heretic. A 'heretic' career of texts written in vulgari was short-lived; in the second half of the fifteenth century, with the development of national literature, it gradually died away. Thus, also the aforementioned element of the heretic's image disintegrated. In social reception the image of the heretic, simplified and undoubtedly poorer than the model in various disciplines of elitist knowledge, in scholarly literature, and also in the emotional stream of communication, consisting of individual, most strongly inculcated and memorable elements, was constantly and invariably associated with the world of values seen as negative. The Church teaching linked it too strongly with the forces of evil and sin to make it possible for this image to change in people's thinking and feeling under the influence of increasingly critical attitudes. Religious and ethical models and anti-models crumbled only

77 Cf. E. Potkowski, 'Pismo i społeczeństwo w Polsce późnego średniowiecza', Przeglad Humanistyczny, 1979, 1, pp. 52-53 (Chapter 2: 'Pismo jako instrument polityki i propagandy').

78 During interrogations of witnesses and the accused of dissemination of Hussite errors in Pakość in Great Poland someone was mentioned who 'scribebat quendam librum mixtum de polonico et latino', while the local sacristan stated: 'an docuisset aliquem virum aut mulierem lecturam vulgarem aut Bohemicalem, respondit quod non' - A. Cap., vol. 2 (Acta iud. eccl. Gneznensis), p. 198 ff. (1455). Cf. also Potkowski, Pismo ..., op. cit., p. 53.

79 A. Cap., vol. 2 (Acta iud. eccl. Gneznensis), pp. 197-99.

80 Cf. E. Potkowski, 'Książka w społeczeństwie polskim schyłku średniowiecza (XIV-XV w.)', Przeglad Humanistyczny, 1982, 1-2, p. 7. 
with great difficulty. Let us remind here that people accused of heresy never considered themselves heretics, but thought of themselves as of orthodox Christians, true followers of the Gospel of Jesus Christ. Czech Hussites regarded their name of heretics as false and discreditable, calling themselves 'Brethren', 'the God's faithful', 'the faithful Bohemians' etc. Although in Polish sources of Church courts we find a man who was able and had courage to state: 'There are many heretics and I am one of them', ${ }^{81}$ but he belonged to the next generation of the Reformation's participants.

But that evil, sinful heretic known in the Polish society of the fifteenth century lost many of the traits attributed to him of a dangerous wolf lurking for prey of people, a messenger of Satan threatening the soul of man, or a criminal - a public enemy. Because his name entered the informal spoken language, he became domesticated. He was also a subject of parody and mockery in unofficial literature that, in any case, poorly responded to Hussitism. ${ }^{82}$ Hussite Bruchrinek from a text written within the milieu of the chancellery ${ }^{83}$ is a figure from the world of both mockery and contempt: he is a pompous, cowardly and ugly jackanapes. As it seems, it is contempt that connects this literary personage with feelings of people towards heretics - persons who gained lasting infamy, excluded from the Christian community.

In the image of the heretic shaped in fifteenth-century Poland we could find the consequences of accelerated reduction of backwardness in the sphere of antiheretical polemics. The thus created image was for immediate usage, connected with current anti-Hussite actions. And this was the reason why he was deprived of the traits of universal reflection, present in great heresiological summae and inquisitorial handbooks shaping the personage of heretic as the foe of the Universal Church in the past, present and future. In comparison with his counterpart from

81 A. Cap., vol. 3 (Acta iud. eccl. Plocensis), p. 104 (1506): 'assereret et diceret, quod in hostia, quam sacerdos elevat, non sit Christus verus, sed panis purus; et dicebat insuper: Sunt multi heretici et ego sum unus de eis'.

82 The echoes of Hussitism in literature were discussed by K. Kolbuszewski, Ruchy husyckie w Polsce i wptyw ich na piśmiennictwo, Cracow, 1922 (first published in Reformacja w Polsce, 1, 1921, 3).

83 An edict against Bruchrinek Hussite in Codex epistolaris Vitoldi, p. 1065. Cf. on the subject J. Nowak-Dłużewski, Okolicznościowa poezja polityczna w Polsce. Średniowiecze, Warsaw, 1963, pp. 62-65, 133. 
Western Europe we could also find some anachronisms and symptoms of certain insensibility to great themes of contemporary heresiology, ${ }^{84}$ debating over the problems almost unknown in Poland. But it was not a manifestation of backwardness of Polish religious, theological and legal culture in the Late Middle Ages, but of Polish different reality. Different were ideological and religious contents fought against as heretical, different were attitudes and aspirations thought of as heretical. It is worth to remember, however, that the analysed image of the heretic was shaped in specific circumstances of a state which issued severe regulations against the foes of the true faith and the Church, but at the same time was reluctant to implement them too fervently.

Translated by Grażyna Waluga

First published as: 'Wizerunek heretyka w Polsce późnośredniowiecznej', Odrodzenie i Reformacja $w$ Polsce, 30, 1985, pp. 5-24.

84 The issue of great polemics around heresy in the late Middle Ages was presented by J.-C. Schmitt, Mort d'une hérésie. L'Eglise et les clercs face aux béguines et aux béghards du Rhin supérieur du XIV au XV siècle, Paris, La Haye, and New York, 1978. 